\title{
Case 3119
}

\section{VACHONIAINAE Maury, 1973 (Arachnida, Scorpiones): proposed conservation as the correct spelling to remove homonymy with vachoniIdae Chamberlin, 1947 (Arachnida, Pseudoscorpiones)}

\author{
Victor Fet
}

Department of Biological Sciences, Marshall University, West Virginia 25755,U.S.A. (e-mail: fet@marshall.edu)

\section{Matt E. Braunwalder}

Frauentalweg 97, CH-8045 Zürich, Switzerland (e-mail: admin@arachnodata.ch)

Abstract. The purpose of this application is to remove the homonymy between two arachnid family-group names, VACHONIIDAE Chamberlin, 1947 (Pseudoscorpiones; type genus Vachonium Chamberlin, 1947) and VACHONIINAE Maury, 1973 (Scorpiones; type genus Vachonia Abalos, 1954). It is proposed that the entire generic name of Vachonia should be adopted as the stem, so that the correct spelling of the scorpion subfamily name will be VACHONIAINAE Maury, 1973.

Keywords. Nomenclature: taxonomy; Arachnida; Pseudoscorpiones; Scorpiones; BOTHRIURIDAE; VACHONIAINAE; VACHONIIDAE; Vachonia; Vachonium.

1. Chamberlin $(1947$, p. 3 ) based the pseudoscorpion family VACHONIIDAE on his simultaneously established nominal genus Vachonium (p. 4; type species Vachonium boneti Chamberlin, 1947 (p. 6) by original designation). This family is in general use, and currently includes two genera and 12 species (Harvey, 1990).

2. Maury $(1973$, p. 30$)$ published the scorpion subfamily name VACHONIANINAE [sic], based on Vachonia Abalos, 1954 (p. 119, type species Vachonia martinezi Abalos, 1954 (p. 120) by original designation, family BOTHRIURIDAE Simon, 1880). Like Vachonium, Vachonia was derived from the name of the French arachnologist Max Vachon (1908-1991). The name VACHONIANINAE is an incorrect original spelling of VACHONIINAE, since under the Code (Article 29.3 of the 1999 edition) the grammatical stem of Vachonia is Vachoni- and not Vachonian-. However, VACHONIINAE cannot be used for a scorpion taxon because (with change of suffix) it is a junior homonym of the pseudoscorpion name VACHONIIDAE Chamberlin, 1947 (para. 1 above). Maury's name has been used (Francke, 1982; Sissom, 1990); although at subfamily rank it has recently been synonymized with the nominotypical subfamily BOTHRIURINAE by Maury himself (Acosta \& Maury, 1998, p. 559; see also Lowe, 2000), elimination of the homonymy is necessary for use at any rank (such as tribe) and the case is referred to the Commission for a ruling under Article 55.3. In accordance with Recommendation $29 \mathrm{~A}$ of the Code we propose that the entire generic name Vachonia should be used as the grammatical stem, so that Maury's 
name should be spelled VACHONIAINAE and thus not be a junior homonym of VACHONIIDAE Chamberlin.

3. The International Commission on Zoological Nomenclature is accordingly asked:

(1) to use its plenary power to rule that for purposes of Article 55.3.1 of the Code the stem of the generic name Vachonia Abalos, 1954 (Arachnida, Scorpiones) is VACHONIA-;

(2) to place on the Official List of Generic Names in Zoology the following names:

(a) Vachonia Abalos, 1954 (gender: feminine), type species Vachonia martinezi Abalos, 1954 by original designation;

(b) Vachonium Chamberlin, 1947 (gender: neuter), type species Vachonium boneti Chamberlin, 1947 by original designation;

(3) to place on the Official List of Specific Names in Zoology the following names:

(a) martinezi Abalos, 1954, as published in the binomen Vachonia martinezi (specific name of the type species of Vachonia Abalos, 1954);

(b) boneti Chamberlin, 1947, as published in the binomen Vachonium boneti (specific name of the type species of Vachonium Chamberlin, 1947);

(4) to place on the Official List of Family-Group Names in Zoology the following names:

(a) VACHONIAINAE Maury, 1973 (type genus Vachonia Abalos, 1954 (correct spelling of VACHONIANINAE by the ruling in (1) above);

(b) VACHONIIDAE Chamberlin, 1947 (type genus Vachonium Chamberlin, 1947);

(5) to place on the Offical Index of Rejected and Invalid Family-Group Names in Zoology the name VACHONIANINAE Maury, 1973 (an incorrect original spelling of VACHONIAINAE).

\section{References}

Abalos, J.W. 1954. Vachonia, nuevo género de escorpiones. Anales del Instituto de Medicina Regional, Universidad de Tucumán, 4(1): 119-124

Acosta, L.E. \& Maury, E.A. 1998. Scorpiones. Pp. 545-559 in Morrone, J.J. \& Coscarón, S. (Eds.), Biodiversidad de Artropodos Argentinos. Ediciones Sur, La Plata.

Chamberlin, J.C. 1947. The Vachoniidae - a new family of false scorpions represented by two new species from caves in Yucatan. Bulletin of the University of Utah, Biological Series, 38 : $1-15$.

Francke, O.F. 1982. Are there any bothriurids (Arachnida, Scorpiones) in southern Africa? Journal of Arachnology, 10: 35-40.

Harvey, M.S. 1990. Catalogue of the Pseudoscorpionida. 726 pp. University of Manchester Press, Manchester.

Lowe, G. 2000. Family Bothriuridae. Pp. 17-53 in Fet, V., Sissom, W.D., Lowe, G. \& Braunwalder, M.E., Catalog of the scorpions of the world (1758-1998). 690 pp. New York Entomological Society, New York.

Maury, E.A. 1973. Essai d'une classification des sous-familles de scorpions Bothriuridae. Pp. 29-36 in: Proceedings of the 5th International Congress of Arachnology (Brno, 1971).

Sissom, W.D. 1990. Chapter 3. Systematics, biogeography and paleontology. Pp. 64-160 in Polis, G.A. (Ed.), Biology of scorpions. 587 pp. Stanford University Press, Stanford.

Comments on this case are invited for publication (subject to editing) in the Bulletin; they should be sent to the Executive Secretary, I.C.Z.N., c/o The Natural History Museum, Cromwell Road, London SW7 5BD, U.K. (e-mail: iczn@nhm.ac.uk). 


\section{$2 \mathrm{BHL}$ Biodiversity Heritage Library}

Fet, Victor and Braunwalder, Matt E. 2000. "VACHONIAINAE Maury, 1973 (Arachnida, Scorpiones): proposed conservation as the correct spelling to remove homonymy with VACHONIIDAE Chamberlin, 1947 (Arachnida, Pseudoscorpiones)." The Bulletin of zoological nomenclature 57, 24-25. https://doi.org/10.5962/bhl.part.20662.

View This Item Online: https://www.biodiversitylibrary.org/item/45022

DOI: https://doi.org/10.5962/bhl.part.20662

Permalink: https://www.biodiversitylibrary.org/partpdf/20662

\section{Holding Institution}

Natural History Museum Library, London

\section{Sponsored by}

Natural History Museum Library, London

\section{Copyright \& Reuse}

Copyright Status: In copyright. Digitized with the permission of the rights holder.

License: http://creativecommons.org/licenses/by-nc-sa/3.0/

Rights: https://biodiversitylibrary.org/permissions

This document was created from content at the Biodiversity Heritage Library, the world's largest open access digital library for biodiversity literature and archives. Visit BHL at https://www.biodiversitylibrary.org. 